\title{
Foraging behaviour of the long-fingered bat Myotis capaccinii: implications for conservation and management
}

\author{
David Almenar, Joxerra Aihartza, Urtzi Goiti, Egoitz Salsamendi, Inazio Garin*
}

Zoologia Saila, Universidad del País Vasco/Euskal Herriko Unibertsitatea (UPV/EHU), 644 PK, 48080 Bilbao, The Basque Country

\begin{abstract}
The main factors threatening Myotis capaccinii (Bonaparte, 1837) are considered to be foraging habitat degradation and roost loss. Conservation strategies that focus on the protection of roosts are feasible as long as direct threats by human activities are correctly identified. However, before protection of foraging habitat can be implemented more accurate information is required. We review the available information of relevance to foraging habitat management for the species. Three main topics are considered based on the results of a radiotelemetry study on 45 ind. in 3 seasons: habitat dependence, features of foraging habitat, and spatial range. $M$. capaccinii foraged almost completely over aquatic habitats as in other telemetry studies. We discuss the importance of terrestrial habitats and the dependence of the species on aquatic habitats. It has been proposed that several factors affect habitat selection in this species. The presence of smooth, clutter-free water surfaces seems to be the most important structural factor, but we found that prey richness also affected habitat selection. Effects of features related to riparian vegetation and water quality are thought to vary according to local conditions. Preference for wide water bodies is probably linked to preference for smooth surfaces, where detection and trawling of prey is favoured. As highlighted by recent telemetry studies, we observed M. capaccinii foraging at long distances from the roost. Therefore, the area of application for conservation measures should be large: we suggest a protection radius of $20 \mathrm{~km}$ around roosts.
\end{abstract}

KEY WORDS: Myotis capaccinii $\cdot$ Bats $\cdot$ Conservation $\cdot$ Management $\cdot$ Foraging $\cdot$ Aquatic habitats

\section{INTRODUCTION}

The long-fingered bat Myotis capaccinii (Bonaparte, 1837 ) is a cave-dwelling species (Papadatou et al. 2008) distributed throughout the Mediterranean basin and southwestern Asia (Hutson et al. 2001, Spitzenberger \& von Helversen 2001). It forages mainly on aquatic habitats (Almenar et al. 2006, Biscardi et al. 2007), where it takes prey directly from or above the water surface (Kalko 1990, Almenar et al. 2008). M. capaccinii is Vulnerable (Hutson et al. 2001, 2008) and its populations in western Europe are especially threatened (Guillén 1999).

Typically, 3 main threats are recognised as affecting bats: pesticide contamination, roost disappearance or disturbance, and alteration of foraging areas (Hutson et al. 2001, Racey \& Entwistle 2003). Myotis capaccinii strictly depends on underground shelters (Papadatou et al. 2008) and the alteration or disturbance of breeding roosts has resulted in local extinctions (Almenar et al. 2007). Guillén (1999) proposed that disappearance of foraging habitat and roosts is the main cause of regression for the species in western Europe. Médard \& Guibert (1990) suggested that the alteration of Mediterranean rivers has been a major cause of its regression in France. The effects of pesticides have not been examined for $M$. capaccinii but are thought to be deleterious, as for other species (e.g. Clark et al. 1988, Gerell \& Lundberg 1993, Guillen et al. 1994, Clark 2001). In fact, its typical prey (chironomids) are known to accumulate toxic compounds (Reinhold et al. 1999). 
For cave-dwelling bats, conservation strategies that focus on the protection of roosts are feasible as long as direct threats by human activities are correctly identified. Areas of the landscape suitable for future protective actions can easily be identified, need relatively low resource investment, and raise few socioeconomic disputes. On the other hand, more accurate information is needed before protection of foraging habitat can be implemented into bat conservation strategies. Because cave-dwelling bats usually use a large area around the roost (e.g. Adam et al. 1994, Russo et al. 2002, 2005, Goiti et al. 2006) and limitation of human activities over vast land extensions is seldom possible, conservation guidelines should be as precise as possible. Comprehensive information about key habitat features and actual foraging ranges is therefore necessary for the optimisation of conservation measures applicable to foraging areas.

Prior to the beginning of the 21st century, knowledge about the life history of Myotis capaccinii was limited, especially as regards its foraging ecology; these data were scarce, fragmentary, and usually based on personal observations or even mere opinions (see Cosson \& Médard 1999 for a review). We believe that a basic model on the foraging ecology of the species is lacking. Firstly, some fundamental topics relevant to the management of its foraging habitat remain obscure. For instance, data published to date do not agree on the relative use of terrestrial and aquatic environments by $M$. capaccinii. In Corsica, Courtois (1998) captured the species only on aquatic habitats, although the mist-nets used in trapping were not allocated in proportion to habitat availability. Carmel \& Safriel (1998) and Russo \& Jones (2003) also identified aquatic habitats as those most frequently used by $M$. capaccinii; however, in several instances observations have also been made over terrestrial habitats (Cosson \& Médard 1999, Lanza \& Agnelli 2000, Spitzenberger \& von Helversen 2001, Davy et al. 2007). Secondly, sound knowledge about the autoecology of $M$. capaccinii has been published only recently. The number of studies on diet (Aihartza et al. 2003, Levin et al. 2006, Biscardi et al. 2007, Almenar et al. 2008), factors affecting foraging behaviour, and the spatial range of foraging individuals is now remarkable (Almenar et al. 2006, Biscardi et al. 2007, Némoz \& Brisorgueil 2008, Aihartza et al. 2008). Moreover, 2 of these are radiotracking studies with a significant number of individuals surveyed, 21 in Italy (Biscardi et al. 2007) and 33 in France (Némoz \& Brisorgueil 2008), which improves considerably the quality of available data on the foraging ecology of the species and thus allows a more comprehensive framework for conservation strategies to be proposed.

The present study, using the results gathered from a group of 45 radiotracked individuals (enlarging the sample from Almenar et al. 2006), specifically addressed the following topics: (1) the level of use of terrestrial environments by Myotis capaccinii; (2) the effect of the type of water body on foraging intensity; precisely, level of clutter on the water surface, water quality, presence of riparian vegetation, width of water bodies, and availability of prey; and (3) the spatial range used by $M$. capaccinii for foraging.

\section{MATERIALS AND METHODS}

Study area, bat population, and roosts. The study area, in the eastern Iberian Peninsula (39 $04^{\prime} \mathrm{N}$, $0^{\circ} 35^{\prime} \mathrm{W}$ ), belongs to the termo-Mediterranean domain (Sanchis-Moll 1988) and is located in the low basin of the Xúquer River. The basin includes several tributaries, the most important being the Albaida and Sellent Rivers. The flow of these tributaries shows some degree of Mediterranean seasonality. Rivers are managed through a large dam (Presa de Tous), many small weirs, and a vast network of irrigation channels. There are also several ponds (about 3 per $\mathrm{km}^{2}$ ). Approximately two-thirds of the study area is comprised of a large floodplain (20 to $50 \mathrm{~m}$ above sea level [a.s.l.]) mainly covered by orange groves. The remaining area is a hilly landscape (max. altitude $=600 \mathrm{~m}$ a.s.l.) covered by Mediterranean vegetation.

The area harbours one of the most important breeding populations of this species in the Iberian Peninsula. Some roosts in the area are inhabited by groups of Myotis capaccinii during the breeding season. The main roost is a limestone cave. The size of this colony is highly variable within and between years (150 to 500 ind.). This fluctuation in roost use is typical for the species (Courtois 1998, Papadatou et al. 2008). Sex ratio is also variable throughout the year.

Study design, data collection, and analyses. The study was divided into 3 periods corresponding to 3 relevant phases of the bats' annual cycle: pre-breeding (9-30 April 2004), lactation (24 May-11 June 2004), and post-lactation (1-17 July 2004).

Using a harp trap (Tuttle 1974), we captured 62 bats returning to the main roost after their nightly foraging. We performed 2 trapping sessions per period. Each bat was sexed, aged, measured, and radio-tagged. After clipping the fur between the bat's shoulder blades, we attached a $0.45 \mathrm{~g}$ PIP II radiotransmitter (Biotrack) with Skinbond surgical adhesive (Smith \& Nephew). The transmitter represented less than $5 \%$ of the bat's weight (Aldridge \& Brigham 1988), except for 11 cases in which it represented up to $6.3 \%$. Capture, manipulation, and tagging were performed with permission of the Valencian Government. 
The bats were tracked by car or on foot from emergence to return. Up to 6 simultaneous tracking teams were equipped with either 1000-XRS radio-receivers (Wildlife Materials) or FT-290RII units (A. Wagener Telemetrieanlagen) and with 3-element Yaggi antennae. Two or 3 bats were tracked each night. Fixes were obtained by homing-in (White \& Garrot 1990), and consecutive fixes were recorded every $10 \mathrm{~min}$ to avoid temporal pseudoreplication. Activity consisting of direct and quick dis- placements between roost and foraging sites or between 2 separate foraging locations was classified as commuting. Motionless, usually weak signals coming from a shelter were classified as resting. Back-and-forth movements over a restricted location were classified as foraging. Fixes were mapped in the field on orthoimages or 1:10000 topographic maps and subsequently transferred into GIS (ArcView 3.2, ESRI). The 15 bats with the most foraging fixes in each period were selected for the analyses (Table 1).

We defined the colony home range by the minimum convex polygon (White \& Garrot 1990) that enclosed all fixes. Habitats within the home range were mapped in GIS (ArcView 3.2, ESRI) using orthoimages (Institut Geogràfic Valencià, 4 pixels $\mathrm{m}^{-2}$ resolution) and field surveys. All terrestrial habitat were coded in a single category. Aquatic habitats were classified into 4 categories: rivers (including small weirs), canals (wider than $2 \mathrm{~m}$ ), ponds $\left(>100 \mathrm{~m}^{2}\right)$, and the reservoir. Water bodies were additionally classified into 3 categories of surface clutter: smooth, rippled, or covered by vegetation. They were further classified according to the associated riparian vegetation: trees/bushes (Populus spp., Nerium oleander, Tamarix spp., and other), reeds (Arundo donax), or absent. Width of water bodies was classified as $<5 \mathrm{~m}, 5$ to $10 \mathrm{~m}$, and $>10 \mathrm{~m}$.

Aquatic habitat type, surface clutter, riparian vegetation, and water body width were analysed for resource preference, comparing the proportion of individual fixes in a given feature category (hereafter referred to as 'use') and their relative availability in the whole home range (Table 2). We followed Aebischer et al. (1993) to test the hypothesis of non-random habitat use. Because in some instances some categories received no use and the method of zero substitution proposed by Aebischer et al. (1993) can increase type I error in this circumstance (Pendleton et al. 1998, Bingham \& Brennan 2004), we followed
Pendleton et al. (1998) and simulated, under the hypothesis of no selection, the distribution of Wilk's statistic to compare the calculated value with the actual data. We ran 5000 Monte Carlo simulations using a multinomial distribution with the available proportions as cell probabilities and the number of fixes as the number of events. All computations were

Table 1. Myotis capaccinii. Capture and radio-tracking characteristics of 45 individuals during the 3 periods of the present study. AF: adult female; AM: adult male; L: lactating female; P: pregnant female; JF: juvenile female; JM: juvenile male. Days: no. days with radiolocations; Fixes: total no. fixes

\begin{tabular}{|c|c|c|c|c|}
\hline Study period & $\begin{array}{l}\text { Capture date } \\
\text { (mm/dd/yy) }\end{array}$ & Characteristic & Days & Fixes \\
\hline \multirow[t]{15}{*}{ Pre-breeding } & $4 / 9 / 04$ & $\mathrm{AF}$ & 3 & 41 \\
\hline & & $\mathrm{AF}$ & 4 & 36 \\
\hline & & $\mathrm{AM}$ & 4 & 45 \\
\hline & & $\mathrm{AM}$ & 8 & 132 \\
\hline & & $\mathrm{AF}$ & 5 & 60 \\
\hline & & $\mathrm{AF}$ & 2 & 44 \\
\hline & & $\mathrm{AF}$ & 4 & 140 \\
\hline & & $\mathrm{AM}$ & 6 & 105 \\
\hline & & $\mathrm{AM}$ & 5 & 78 \\
\hline & $4 / 17 / 04$ & $\mathrm{AF}$ & 3 & 50 \\
\hline & & $\mathrm{AM}$ & 3 & 43 \\
\hline & & $\mathrm{AF}$ & 1 & 19 \\
\hline & & $\mathrm{AM}$ & 2 & 14 \\
\hline & & $\mathrm{AM}$ & 5 & 55 \\
\hline & & $\mathrm{AM}$ & 1 & 17 \\
\hline \multirow[t]{15}{*}{ Lactation } & $5 / 24 / 04$ & $\mathrm{AF}$ & 2 & 17 \\
\hline & & $\mathrm{L}$ & 4 & 28 \\
\hline & & $\mathrm{AM}$ & 3 & 30 \\
\hline & & $\mathrm{L}$ & 3 & 18 \\
\hline & & $\mathrm{L}$ & 4 & 47 \\
\hline & & $\mathrm{L}$ & 1 & 22 \\
\hline & $6 / 4 / 04$ & $\mathrm{~L}$ & 4 & 34 \\
\hline & & $\mathrm{L}$ & 1 & 20 \\
\hline & & $\mathrm{L}$ & 4 & 38 \\
\hline & & $\mathrm{AM}$ & 2 & 50 \\
\hline & & $\mathrm{P}$ & 2 & 42 \\
\hline & & $\mathrm{L}$ & 2 & 14 \\
\hline & & $\mathrm{L}$ & 1 & 41 \\
\hline & & $\mathrm{AF}$ & 1 & 23 \\
\hline & & $\mathrm{L}$ & 2 & 50 \\
\hline \multirow[t]{15}{*}{ Post-lactation } & $7 / 1 / 04$ & $\mathrm{JF}$ & 5 & 90 \\
\hline & & JM & 4 & 64 \\
\hline & & $\mathrm{JF}$ & 7 & 67 \\
\hline & & JM & 5 & 53 \\
\hline & & $\mathrm{JF}$ & 3 & 23 \\
\hline & & $\mathrm{AF}$ & 5 & 75 \\
\hline & & $\mathrm{AF}$ & 3 & 56 \\
\hline & & $\mathrm{AF}$ & 3 & 69 \\
\hline & $7 / 10 / 04$ & JM & 2 & 12 \\
\hline & & $\mathrm{JF}$ & 5 & 14 \\
\hline & & JF & 3 & 36 \\
\hline & & $\mathrm{JF}$ & 2 & 41 \\
\hline & & JM & 4 & 24 \\
\hline & & $\mathrm{AF}$ & 3 & 42 \\
\hline & & $\mathrm{AF}$ & 3 & 27 \\
\hline
\end{tabular}


carried out in Excel and Poptools 2.7 (G. M. Hood). This method is equivalent to the graphical simulation used by Pendleton et al. (1998) and Bingham \& Brennan (2004). We substituted $0.01 \%$ for 'zero' values of use, although explorations with other values provided similar results.

Water quality and prey abundance were sampled in a number of locations. Water quality based on biotic indices of the macroinvertebrate fauna (Alba Tercedor et al. 2002) was known for 12 sites normally included in a local survey of water quality (Red Biológica de Calidad de Aguas, Confederación Hidrográfica del Júcar, www.chj.gob.es/redescalidad/red_biologica.aspx).

Among the 5 categories of the index (from best to worst, I to V), only the middle categories (II to IV) were present in the study area. Because index value varied between years in some places, we chose the values from 2004 if available, or the closest otherwise. Prey density was measured for 88 places in the study area (32 in prebreeding, 24 in lactation, and 32 in post-lactation). A method that emulates trawling behaviour (main foraging style of the species, after Kalko 1990) was used to capture prey. A hand-net $(75 \times 25 \mathrm{~cm}, 1 \mathrm{~mm}$ mesh) was used to drag the water surface for $15 \mathrm{~min}$. Hand-net contents were stored in $70 \%$ ethanol, and the total number of arthropods in the range of sizes captured by the species (Almenar et al. 2008) was subsequently counted. We established 3 categories of prey abundance based on the 33 and $66 \%$ percentiles: poor $(<3.9$ prey $\mathrm{m}^{-2} \mathrm{~min}^{-1}$ ), medium (3.9 to 16.6 prey $\mathrm{m}^{-2} \mathrm{~min}^{-1}$ ), and rich (>16.6 prey $\left.\mathrm{m}^{-2} \mathrm{~min}^{-1}\right)$. The number of radiotelemetry fixes in a given radius from each sampling place (100 $\mathrm{m}$ for prey abundance and $1 \mathrm{~km}$ for water quality) was counted as a measure of use for the site. This included 1090 fixes for the water quality analysis and 759 for the prey abundance. The proportion of sampling sites with a given category was counted as the relative availability of the category. Resource selection analysis was based on Neu et al. (1974), but using the log-linear G-squared statistic instead of the chisquared test for the general hypothesis of independence (Quinn \& Keough 2002) and using Bailey's CI instead of Bonferroni's (Cherry 1996). Preliminary results showed that habitat selection did not show significant variation between classes of individuals or periods (Almenar 2008), so we grouped the classes in the analyses.

\section{RESULTS}

\section{Foraging range}

The colony's home range was $344.6 \mathrm{~km}^{2}$. Bats used a total of $49.2 \mathrm{~km}$ of aquatic habitat, which is $39 \%$ of the available aquatic habitat. The maximum linear dis- tance travelled by a bat from roost to foraging site was $22.7 \mathrm{~km}$, by an adult female in post-lactation. On average, bats foraged $5.6 \mathrm{~km}$ away from the roost $(\mathrm{SD}=$ 3.6). A radius of $10 \mathrm{~km}$ around the main roost contained more than $90 \%$ of the total foraging activity.

\section{Habitat use}

All recorded foraging activity occurred over aquatic habitats (Fig. 1). Only one bat was recorded (for $\sim 10 \mathrm{~min}$ ) flying over terrestrial habitat, and the type of activity could not be ascertained. Overall, bat activity was higher on rivers (91.8\% of overall foraging time), and many bats foraged exclusively on rivers (27 of 45 ). Six ind. also foraged on isolated ponds $(3.6 \%$ of the time), 10 ind. on channels $(2.8 \%$ of the time), and 4 juveniles on the reservoir ( $1.7 \%$ of the time). No bats were recorded foraging in terrestrial habitats.

Bats mainly used aquatic habitats with open, smooth surfaces, and stagnant or slow-flowing waters. The bats foraged either exclusively or partially over smooth waters $(81.2 \%$ of the overall foraging time); up to 35 bats also sometimes foraged over rippled waters $(18.4 \%)$, and only 6 foraged occasionally over surfaces

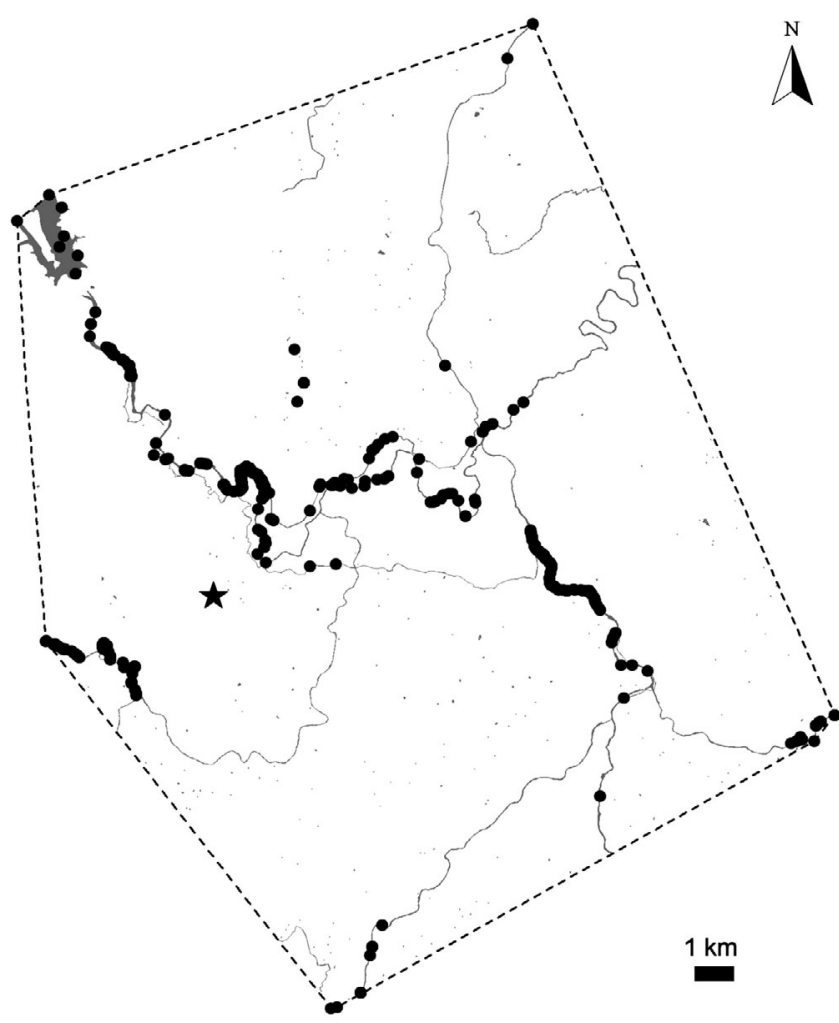

Fig. 1. Study area and radiolocations of 45 Myotis capaccinii in the Lower Xúquer Basin, Iberian Peninsula. (๑): radiolocations; grey shading: aquatic habitats; $(\star)$ : main roost $\left(30^{\circ} 03^{\prime} \mathrm{N}, 0^{\circ} 36^{\prime} \mathrm{W}\right)$ 
covered by vegetation $(0.4 \%)$. Bats foraged mainly in water bodies without riparian vegetation (54.8\%), although river stretches surrounded by dense reed formations or trees/bushes were also used noticeably (29.7 and $15.5 \%$, respectively). The majority of foraging activity (88.4\%) occurred over wide water habitats (width $>10 \mathrm{~m}$ ), but intermediate and small water bodies were also used (9.9 and $1.7 \%$, respectively).

We recorded the highest foraging activity in the sites with Class IV water quality (the lowest in the study area) $81.6 \%$ of the time. Water quality Classes II and III accounted for 0.1 and $18.3 \%$ of the overall foraging time, respectively.

Foraging activity was highest in sites with the richest prey abundance (54.5\% of overall foraging time). Medium and poor prey abundance accounted for 29.5 and $13.3 \%$, respectively, of relative use.

\section{Habitat selection}

The use of different aquatic habitats differed significantly from random (Wilk's $\lambda=0.148, \mathrm{p}<0.001$ ). Rivers were significantly preferred to the other habitats, and isolated ponds and channels were preferred to the reservoir (Table 3 ). The features of the water surface were not used at random $(\lambda=0.109, \mathrm{p}<0.001)$, and smooth water surfaces were preferred to all other surfaces (Table 3). The use of water bodies was significantly linked to the surrounding riparian vegetation $(\lambda=0.743, p=0.003)$; foraging locations without riparian vegetation or reeds were preferred to those with trees and/or bushes (Table 3). Foraging locations were not used randomly regarding width $(\lambda=0.159$, $\mathrm{p}<0.001)$; those $>10 \mathrm{~m}$ wide were preferred to the rest (Table 3).

Table 2. Availability of the water body features in the study area. The proportional availability for all the features and the number of independent water bodies (n) for habitats are given

\begin{tabular}{|lcc|}
\hline Category & \% available & $\mathrm{n}$ \\
\hline Habitat & & \\
River & 52.0 & 7 \\
Pond & 3.5 & 301 \\
Channel & 7.8 & 5 \\
Reservoir & 36.3 & \\
Surface & & \\
Smooth & 63.0 & \\
Rippled & 33.4 & \\
Vegetation & 3.6 & \\
Vegetation & & \\
Trees/bushes & 9.8 & \\
Reeds & 31.0 & \\
Absent & 59.0 & \\
\hline
\end{tabular}

Use differed among sites with contrasting water quality $(G=436.1, \mathrm{p}<0.001)$. Class IV sites (the lowest water quality in the area) were selected for foraging, whereas Class III and II waters were avoided (Table 4). Finally, sites with high prey abundance were selected, whereas sites with low abundance were avoided ( $G=$ 159.0, p < 0.001) (Table 3).

\section{DISCUSSION}

\section{Link to aquatic habitats}

We observed long-fingered bats foraging only over water, consistent with the results of Biscardi et al. (2007) and Némoz \& Brisorgueil (2008), who also used an intensive radiotelemetry scheme to measure the species' habitat use. In fact, Myotis capaccinii is clearly specialised to forage in aquatic habitats; its morphology and foraging behaviour (Norberg \& Rayner 1987 , Kalko 1990, Siemers et al. 2001, Spitzenberger \& von

Table 3. Results of the multiple comparisons of the analysis of habitat preference for 45 Myotis capaccinii, based on Aebischer et al. (1993). Analysis for preference of aquatic habitat type, water surface, associated riparian vegetation, and water body width. For each pair of categories, the $t$-statistic and the p-value are shown for the hypothesis that the difference of log-ratios is not 0 . p-values are calculated by randomisation, as suggested by Aebischer et al. (1993). Categories are ranked in order of preference (from most preferred to least); >>> significant difference

\begin{tabular}{|lcc|}
\hline Parameter & $t$ & $\mathrm{p}$ \\
\hline Aquatic habitat type & & \\
River vs. pond & 13.4 & 0.0002 \\
River vs. channel & 11.49 & 0.0002 \\
River vs. reservoir & 20.27 & 0.0002 \\
Pond vs. channel & 0.46 & 0.6638 \\
Pond vs. reservoir & 4.74 & 0.0002 \\
Channel vs. reservoir & 3.85 & 0.0004 \\
Rank: river >>> pond > channel >>> reservoir & \\
Water surface & $t$ & $\mathrm{p}$ \\
Smooth vs. rippled & 5.15 & 0.0002 \\
Smooth vs. covered by vegetation & 18.91 & 0.0002 \\
Ripples vs. covered by vegetation & 5.98 & 0.0002 \\
Rank: smooth >>> rippled >>> covered by vegetation \\
Associated riparian vegetation & $t$ & $\mathrm{p}$ \\
Trees/bushes vs. reeds & -3.75 & 0.0005 \\
Trees/bushes vs. absent & -2.92 & 0.0055 \\
Reeds vs. absent & -1.19 & 0.2386 \\
Rank: absent > reeds $>>>$ trees/bushes & \multicolumn{2}{c}{} \\
Water body width & $t$ & $\mathrm{p}$ \\
$<5$ vs. 5-10 m & -0.39 & 0.7220 \\
$<5$ vs. $>10$ m & -14.19 & 0.0010 \\
$5-10$ vs. $>10$ m & -7.23 & 0.0010 \\
Rank: >10 >>> 5-10 > <5 m & \multicolumn{2}{c}{} \\
\hline
\end{tabular}


Helversen 2001) are typical of trawling bats, a group of species with convergent foraging styles enabled them to exploit prey efficiently over water surfaces (Norberg \& Rayner 1987, Fenton \& Bogdanowicz 2002).

Commuting routes usually crossed large extensions of terrestrial habitats; however, we could not ascertain foraging activity on them. We recorded one of the tracked bats for about 10 min flying over a terrestrial area, but its activity type was unknown. Similarly, Biscardi et al. (2007) and Némoz \& Brisorgueil (2008) recorded some unidentified activity over terrestrial habitats, and Carmel \& Safriel (1998) and Russo \& Jones (2003) observed some Myotis capaccinii in terrestrial habitats. Further, Davy et al. (2007) detected individuals several times in terrestrial habitats on Zakynthos Island, suggesting that $M$. capaccinii can forage over terrestrial habitats in extremely arid places such as the Ionian Islands. It is then possible that, under suboptimal conditions (Goiti et al. 2003) or in dry seasons, bats modify their foraging behaviour, but the main conclusion for conservation purposes is that $M$. capaccinii fully depends on aquatic habitat in and around the breeding season.

\section{Preferred foraging habitat characteristics}

In the present study, the long-fingered bats' preference for rivers compared to other water bodies was remarkable. Rivers have been reported as the main foraging habitat by Courtois (1998), Russo \& Jones (2003), Biscardi et al. (2007), and Némoz \& Brisorgueil (2008). Nevertheless, Myotis capaccinii has also been found foraging elsewhere, e.g. over isolated ponds (Carmel \& Safriel 1998), water channels (Biscardi et al. 2007), and lakes and reservoirs (Spitzenberger \& von

Table 4. Multiple comparisons of the habitat selection analysis for 45 Myotis capaccinii, based on Neu et al. (1974). Analysis for selection of water quality (from best to worst, Classes II to IV) and prey availability. The comparison of the $95 \%$ Bailey's CI to proportion available allows the assessment of the significance of selection (positive if proportion of use is higher than availability, negative if it is lower); ns: proportions of use and availability do not differ significantly

\begin{tabular}{|c|c|c|c|c|}
\hline & \multicolumn{2}{|c|}{ Bailey's CI } & \multirow{2}{*}{$\begin{array}{c}\text { Proportion } \\
\text { available }\end{array}$} & \multirow[t]{2}{*}{ Selection } \\
\hline & Lower & Upper & & \\
\hline \multicolumn{5}{|c|}{ Water quality } \\
\hline II & 0.001 & 0.006 & 0.083 & Negative \\
\hline III & 0.156 & 0.213 & 0.417 & Negative \\
\hline IV & 0.785 & 0.843 & 0.500 & Positive \\
\hline \multicolumn{5}{|c|}{ Prey availability } \\
\hline Poor & 0.105 & 0.165 & 0.341 & Negative \\
\hline Medium & 0.280 & 0.363 & 0.307 & ns \\
\hline Rich & 0.500 & 0.589 & 0.352 & Positive \\
\hline
\end{tabular}

Helversen 2001, Russo \& Jones 2003, Némoz \& Brisorgueil 2008). Unfortunately, the relative preference for different types of water bodies across Europe cannot be assessed, as selection analysis was not performed in most studies. Almenar et al. (2006) pointed out that rivers are the preferred foraging habitat of the species because they are richer in prey. Moreover, as rivers are spatially connected, bats are able to commute and forage simultaneously.

Myotis capaccinii in the present study preferred water bodies with clutter-free, smooth surfaces, a finding that agrees with other studies (Biscardi et al. 2007, Némoz \& Brisorgueil 2008). Trawling bats are known to prefer foraging on these surfaces (Boonman et al. 1998, Britton \& Jones 1999, Rydell et al. 1999, Warren et al. 2000), where they find advantages related to enhanced object detection and reduced sonic interference (Von Frenckell \& Barclay 1987, Mackey \& Barclay 1989, Siemers et al. 2001, 2005).

The present study confirms that river width is another variable that drives foraging habitat selection in Myotis capaccinii. The species foraged with preference on river sections and other water bodies $>10 \mathrm{~m}$ in width. Biscardi et al. (2007) also concluded that wider rivers or channels were selected for foraging. This general preference could be linked to the presence of stagnant and smooth waters in sites with broad water, which are the preferred kind of foraging surface. In the present study, two-thirds of the foraging activity occurred on these wide, smooth water surfaces, although they represented only a quarter of the available water surface.

Biscardi et al. (2007) concluded that the key feature for habitat conservation of this species is environmental quality, a concept that encompasses the degree of conservation of riparian vegetation and the water quality. Némoz \& Brisorgueil (2008) also considered water quality and preservation of riparian vegetation as key factors for the species' conservation. Well-developed riparian vegetation may contribute additional prey and act as a wind shelter. Arthropods from terrestrial habitats represent an important complement to the species' diet (Almenar et al. 2008), and high wind speed decreases the activity of Myotis capaccinii over water (Russo \& Jones 2003), presumably due to the formation of ripples on the water surface. Riparian vegetation is also an important factor for foraging site selection of $M$. daubentonii (Warren et al. 2000). However, the bats in our study area preferred to forage in sites without riparian vegetation or with dense reed coverage. The steep banks of most of the rivers and channels in our study area, as well as the dense reed formations that border many of the river stretches, could equally minimise the effect of wind. Availability of water habitats with surrounding trees or bushes was quite low $19.8 \%$ 
of the total surface). If this were a true limiting factor, we should expect high foraging activity associated with the few water bodies with wooden riparian vegetation. Therefore, well-developed riparian vegetation does not seem to be a limiting factor for $M$. capaccinii in the present study, and its relevance would depend on the presence of other natural structures that may act as wind-shield.

In the present study, bats foraged over the lowestquality waters available, contradicting the findings of Biscardi et al. (2007) and Némoz \& Brisorgueil (2008). Interestingly, Courtois (1998) did not find any association between water quality and foraging activity in Corsica. The contradiction between studies may correspond to the simple fact that profitable foraging sites could occur at different water qualities. Although several authors (Médard \& Guibert 1990, Biscardi et al. 2007, Némoz \& Brisorgueil 2008) have highlighted the importance of good water quality for the species, none have proposed a biological mechanism that could explain it. The interaction between water quality and foraging by Myotis capaccinii likely occurs through the effect of water quality on the production of insects with aquatic larvae. Water quality indices are usually intended to rank the man-made alteration of aquatic ecosystems by measuring the species composition of aquatic communities. Anthropogenic contamination, however, may originate from difference sources and thus have a variety of effects on different aquatic communities (Alonso \& Camago 2005). Organic matter contamination increases oxygen consumption, promoting the domination of animals tolerant to low oxygenation (Chironomidae and Oligochaeta). An increased production of chironomids (the most consumed prey item of M. capaccinii, Biscardi et al. 2007, Almenar et al. 2008) could benefit the species, as proposed for other trawling bats (Vaughan et al. 1996, Law \& Urquhart 2000, van de Sijpe et al. 2004). Contamination with inorganic nutrients (e.g. phosphates and nitrates) causes eutrophication and favours the growth of floating plants (e.g. Lemna spp.), which, in turn, makes prey detection over water difficult (Boonman et al. 1998). Other sources of contamination, especially heavy metals, pesticides, and PCBs, tend to accumulate in the food webs (Reinhold et al. 1999), ultimately compromising bats' survival and reproduction. Although the different contamination sources are usually associated, their relative importance varies locally. Differences in the origin (urban, agricultural, industrial) of the contamination should have different effects on M. capaccinii's foraging behaviour, which may explain the conflicting results among the aforementioned studies.

As expected, Myotis capaccinii selected the foraging sites with higher prey availability. Prey abundance is one of the most recurrently proposed factors of relevance for bats' foraging, although this assumption is rarely tested (e.g. Saunders \& Barclay 1992, Entwistle et al. 1996, Vaughan et al. 1996, Arlettaz et al. 1997). In this sense, Cosson \& Médard (1999), Almenar et al. (2006), Biscardi et al. (2007), and Némoz \& Brisorgueil (2008) suggested that prey abundance is a factor of great importance for the foraging of $M$. capaccinii.

In general, 2 main features make aquatic habitats preferable for foraging by Myotis capaccinii: clutterfree surfaces with high prey abundance. Other factors such as water quality, associated riparian vegetation, and water body width seem to affect aquatic habitat foraging secondarily, being of local importance or varying with the ecological context.

\section{Spatial range: colonies and individuals}

Colonies of Myotis capaccinii forage over a large spatial range (compared to other species with similar size and wing morphology; see Jones et al. 1995, Fenton 1997, Almenar 2008). The present study and others (Biscardi et al. 2007, Némoz \& Brisorgueil 2008) have shown that some individuals fly long distances to forage, up to $31 \mathrm{~km}$. Travel distance, however, varies between study areas - the average distance was $5.7 \mathrm{~km}$ in the present study and $\leq 13 \mathrm{~km}$ in Némoz \& Brisorgueil 2008-which is likely related to the effect that distribution of habitats and prey around the colonies has on the flying distances to foraging grounds. The specialisation in aquatic habitat, the spread of this habitat, and the high gregariousness of M. capaccinii result in extensive areas of colony use around breeding sites (Almenar 2008). For instance, the colony's home range in our study area was spread over $344.6 \mathrm{~km}^{2}$, but $92 \%$ of the foraging locations were located within a $10 \mathrm{~km}$ radius of the breeding cave.

\section{Application to conservation and management}

Myotis capaccinii is fully dependent on aquatic habitats. An effective conservation policy for this species should be based on the protection of aquatic habitats around roosts. This means that any action that causes drought of water bodies, as well as reduction in water flow of rivers and channels, should be avoided. In this sense, overexploitation of aquifers and inter-basin water transfers should be considered harmful. Where rivers are intensively managed, a minimum water flow should be assured throughout the year.

As stated above, a clutter-free water surface and high prey availability are the 2 most important factors 
for the foraging of Myotis capaccinii. Any transformation of water habitats within the range of a colony of $M$. capaccinii should avoid the alteration of these 2 factors. Thus, some river engineering practices may have deleterious effects on this species. Canalisation of rivers may decrease their suitability, as it reduces the production of prey by altering substrate quality and diversity and increases water speed and turbulence (Brookes 1988). Large dams produce wide aquatic environments, but water temperature is reduced (Val et al. 2003); this, in turn, decreases and delays the emergence of semi-aquatic insects (Frouz et al. 2002, Lobinske et al. 2002), both in the reservoir itself and downstream in the rivers. On the other hand, small weirs could, in some cases, benefit the species by increasing the overall area of open waters with smooth surfaces.

Riparian vegetation should be considered as a secondary factor that affects both the physical structure of the water surface and prey abundance. Although wooded vegetation next to watercourses is surely beneficial to the species, and the conservation and restoration of riparian vegetation would be advisable as a general rule, its relevance at a local scale may depend on the presence of other structures with similar functionality, such as steep riverbanks or dense, reed-like vegetation.

The influence of water quality remains unclear, and the effects of different sources of water contamination (organic, nutrients, and toxic elements) should be studied separately to reach a reliable conclusion with application to habitat management.

The conservation and management of water bodies to improve habitat quality should be carried out in a large area around main roosts. It is difficult to specify the range that should be protected, since many factors may influence the foraging range used by a colony (including spatial arrangement of the preferred habitats, prey productivity, alternative roosts, and number of individuals). In the present study, $90 \%$ of the foraging activity recorded was concentrated in the $10 \mathrm{~km}$ around the roost. Therefore, a protection radius of $10 \mathrm{~km}$ from the main roost seems a reasonable conservation rule for the studied colony. It should be borne in mind that the conservation measures proposed here apply only to aquatic habitats, and that the suggested radius represents a small proportion of the area used by the bats. The protection radius may differ around other roosts. Considering that the average distance flown by bats in the present study $(5.6 \mathrm{~km})$ is less than half the distance recorded for other colonies (Némoz \& Brisorgueil 2008), a protection radius of $20 \mathrm{~km}$ is advised as a conservative rule wherever there is no information about the spatial range of the bat available.
Acknowledgments. We thank all those who kindly helped us in the field; K. Johnson, who edited the manuscript to improve the English; and 4 anonymous referees whose comments improved the quality of the manuscript. This study was part of a LIFE project (LIFE00NAT/E/7337) coordinated by C. Ibáñez, Estación Biológica de Doñana (Consejo Superior de Investigaciones Científicas [CSIC]), and co-funded by the Conselleria de Territori i Habitatge of the Generalitat Valenciana and the European Commission. Support was also provided by the Centro de Protección y Estudio del Medio Natural 'La Granja de El Saler' and University of the Basque Country (UPV/EHU, research grant no. 9/UPV 0076.31015849/2004). D.A. and E.S. were sponsored by the CSIC and UPV/EHU, and U.G. by the Basque Government and UPV/EHU. This study was performed with permission of the Valencian Government.

\section{LITERATURE CITED}

Adam MD, Lacki MJ, Barnes TG (1994) Foraging areas and habitat use of the Virginia big-eared bat in Kentucky. J Wildl Manag 58:462-469

Aebischer NJ, Robertson PA, Kenward RE (1993) Compositional analysis of habitat use from animal radio-tracking data. Ecology 74:1313-1325

Aihartza JR, Goiti U, Almenar D, Garin I (2003) Evidences of piscivory by Myotis capaccinii (Bonaparte, 1837) in Southern Iberian Peninsula. Acta Chiropt 5:193-198

Aihartza JR, Almenar D, Goiti U, Salsamendi E, Garin I (2008) Fishing behaviour in the long-fingered bat Myotis capaccinii (Bonaparte, 1837): an experimental approach. Acta Chiropt 10:287-301

Alba Tercedor J, Jáimez Cuéllar P, Álvarez M, Avilés J and others (2002) Caracterización del estado ecológico de los ríos mediterráneos ibéricos mediante el índice IBMWP (antes BMWP'). Limnetica 21:175-185 (Spanish with English Abstract)

Aldridge HDJN, Brigham RM (1988) Load carrying and maneuverability in an insectivorous bat: a test of the $5 \%$ 'rule' of radio-telemetry. J Mammal 69:379-382

Almenar D (2008) Uso y selección de recursos por el murciélago patudo (Myotis capaccinii): presas, hábitats y áreas de caza. PhD thesis, University of the Basque Country, Leioa

Almenar D, Aihartza J, Goiti U, Salsamendi E, Garin I (2006) Habitat selection and spatial use by the trawling bat Myotis capaccinii (Bonaparte, 1837). Acta Chiropt 8: 157-167

Almenar D, Alcocer A, Monsalve MA (2007) Myotis capaccinii. Murciélago ratonero patudo. In: Palomo JL, Gisbert J, Blanco JC (eds) Atlas y libro rojo de los mamíferos terrestres de España. Dirección General para la Biodiversidad-SECEM-SECEMU, Madrid, p 194-198

- Almenar D, Aihartza J, Goiti U, Salsamendi E, Garin I (2008) Diet and prey selection in the trawling long-fingered bat. J Zool (Lond) 274:340-348

Alonso A, Camago JA (2005) Estado actual y perspectivas en el empleo de la comunidad de macroinvertebrados bentónicos como indicadora del estado ecológico de los ecosistemas fluviales españoles. Ecosistemas 14. Available at www.revistaecosistemas.net/articulo.asp? Id=133 (with English Abstract)

> Arlettaz R, Perrin N, Hausser J (1997) Trophic resource partitioning and competition between the two sibling bat species Myotis myotis and Myotis blythii. J Anim Ecol 66: 897-911 
Bingham RL, Brennan LA (2004) Comparison of type I error rates for statistical analyses of resource selection. J Wildl Manag 68:206-212

Biscardi S, Russo D, Casciani V, Cesarini D, Mei M, Boitani L (2007) Foraging requirements of the endangered long-fingered bat: the influence of micro-habitat structure, water quality and prey type. J Zool (Lond) 273:372-381

Boonman AM, Boonman M, Bretschneider F, Van de Grind WA (1998) Prey detection in trawling insectivorous bats: duckweed affects hunting behaviour in Daubenton's bat, Myotis daubentonii. Behav Ecol Sociobiol 44:99-107

Britton ARC, Jones G (1999) Echolocation behaviour and prey-capture success in foraging bats: laboratory and field experiments on Myotis daubentonii. J Exp Biol 202: 1793-1801

Brookes A (1988) Channelized rivers: perspectives for environmental management. John Wiley \& Sons, Chichester

Carmel Y, Safriel U (1998) Habitat use by bats in a Mediterranean ecosystem in Israel: conservation implications. Biol Conserv 84:245-250

Cherry S (1996) A comparison of confidence interval methods for habitat use-availability studies. J Wildl Manag 60: $653-658$

Clark DR Jr (2001) DDT and the decline of free-tailed bats (Tadarida brasiliensis) at Carlsbad Cavern, New Mexico. Arch Environ Contam Toxicol 40:537-543

Clark DR Jr, Bagley FM, Johnson WW (1988) Northern Alabama colonies of the endangered gray bat Myotis grisescens organochlorine contamination and mortality. Biol Conserv 43:213-226

Cosson E, Médard P (1999) Murin de Capaccini, Myotis capaccinii (Bonaparte, 1837). In: Roué SY, Barataud M (eds) Habitats et activité de chasse des chiroptères menacés en Europe: synthèse de connaissances actuelles en vue d'une gestion conservatrice Rhinolophe. Museum d'Histoire Naturelle, Geneve, p 47-51

Courtois J (1998) Contribution à la connaissance de la répartition et des caractéristiques biologiques du murin de Capaccini (Myotis capaccinii) en Corse. Arvicola 10:42-46

Davy CM, Russo D, Fenton MB (2007) Use of native woodlands and traditional olive groves by foraging bats on a Mediterranean island: consequences for conservation. J Zool (Lond) 273:397-405

Entwistle AC, Racey PA, Speakman JR (1996) Habitat exploitation by a gleaning bat, Plecotus auritus. Philos Trans R Soc Lond B Biol Sci 351:921-931

Fenton MB (1997) Science and the conservation of bats. J Mammal 78:1-14

Fenton MB, Bogdanowicz W (2002) Relationships between external morphology and foraging behaviour: bats in the genus Myotis. Can J Zool 80:1004-1013

Frouz J, Ali A, Lobinske RJ (2002) Influence of temperature on developmental rate, wing length, and larval head capsule size of pestiferous midge Chironomus crassicaudatus (Diptera: Chironomidae). J Econ Entomol 95:699-705

Gerell R, Lundberg KG (1993) Decline of a bat Pipistrellus pipistrellus population in an industrialized area in south Sweden. Biol Conserv 65:153-157

Goiti U, Aihartza JR, Garín I, Zabala J (2003) Influence of habitat on the foraging behaviour of the Mediterranean horseshoe bat, Rhinolophus euryale. Acta Chiropt 5:75-84

> Goiti U, Aihartza JR, Almenar D, Salsamendi E, Garin I (2006) Seasonal foraging by Rhinolophus euryale (Rhinolophidae) in an Atlantic rural landscape in northern Iberian Peninsula. Acta Chiropt 8:141-156

Guillén A (1999) Myotis capaccinii. In: Mitchell-Jones AJ, Amori G, Bogdanowicz W, Krystufek B and others (eds)
The atlas of European mammals. T \& AD Poyser, London, p 106-107

Guillen A, Ibanez C, Perez JL, Hernandez LM, Gonzalez MJ, Fernandez MA, Fernandez R (1994) Organochlorine residues in Spanish common pipistrelle bats (Pipistrellus pipistrellus). Bull Environ Contam Toxicol 52:231-237

Hutson AM, Spitzenberger F, Aulagnier S, Juste J, Karatafl A, Palmeirim J, Paunoviç M (1996) Myotis capaccinii. In: IUCN (ed) IUCN Red List of threatened species. Available at www.iucnredlist.org

Hutson AM, Mickleburgh SP, Racey PA (2001) Microchiropteran bats. Global status survey and conservation action plan. IUCN, Gland

Jones G, Duvergé L, Ransome RD (1995) Conservation biology of an endangered species: field studies of greater horseshoe bats. Symp Zool Soc Lond 67:309-324

Kalko E (1990) Field study on the echolocation and hunting behaviour of the long-fingered bat, Myotis capaccinii. Bat Res News 31:42-43

Lanza B, Agnelli P (2000) Long fingered bat. Myotis capaccinii (Bonaparte 1837). In: Spagnesi M, Catalano U, Toso $\mathrm{S}$, De Marinis AM (eds) Italian mammals. Istituto Nazionale per la fauna Selvatica, A. Ghigi, Ozzano dell' Emmilia, p 57-58

Law B, Urquhart CA (2000) Diet of the large-footed myotis Myotis macropus at a forest stream roost in northern New South Wales. Aust Mammal 22:121-124

Levin E, Barnea A, Yovel Y, Yom Tov Y (2006) Have introduced fish initiated piscivory among the long-fingered bat? Mamm Biol 71:139-143

Lobinske RJ, Ali A, Frouz J (2002) Laboratory estimation of degree-day developmental requirements of Glyptotendipes paripes (Diptera: Chironomidae). Environ Entomol 31:608-611

Mackey RL, Barclay RMR (1989) The influence of physical clutter and noise on the activity of bats over water. Can J Zool 67:1167-1170

Médard P, Guibert E (1990) Disparition d'un milieu et raréfaction d'une espèce en France: le murin de Capaccini, Myotis capaccinii (Bonaparte, 1837). Mammalia 54: 297-300

Némoz M, Brisorgueil A (2008) Connaissance et conservation des gîtes et habitats de chasse de 3 Chiroptères cavernicoles. Société Française pour l'Etude et la Protection des Mammifères, Toulouse

> Neu CW, Byers CR, Peek JM (1974) A technique for analysis of utilization-availability data. J Wildl Manag 38:541-545

> Norberg UM, Rayner JMV (1987) Ecological morphology and flight in bats (Mammalia: Chiroptera): wing adaptations, flight performance foraging strategy and echolocation. Philos Trans R Soc Lond B Biol Sci 316:335-427

Papadatou E, Butlin RK, Altringham JD (2008) Seasonal roosting habits and population structure of the long-fingered bat Myotis capaccinii in Greece. J Mammal 89:503-512

> Pendleton GW, Titus K, DeGayner E, Flatten CJ, Lowell RE (1998) Compositional analysis and GIS for study of habitat selection by goshawks in southeast Alaska. J Agric Biol Environ Stat 3:280-295

Quinn GP, Keough MJ (2002) Experimental design and data analysis for biologists. Cambridge University Press, Cambridge

Racey PA, Entwistle A (2003) Conservation ecology of bats. In: Kunz TH, Fenton MB (eds) Bat ecology. University of Chicago Press, Chicago, IL, p 680-743

> Reinhold JO, Hendriks AJ, Slager LK, Ohm M (1999) Transfer of microcontaminants from sediment to chironomids, and the risk for the pond bat Myotis dasycneme (Chiroptera) 
preying on them. Aquat Ecol 33:363-376

Russo D, Jones G (2003) Use of foraging habitats by bats in a Mediterranean area determined by acoustic surveys: conservation implications. Ecography 26:197-209

Russo D, Jones G, Migliozzi A (2002) Habitat selection by the Mediterranean horseshoe bat, Rhinolophus euryale (Chiroptera: Rhinolophidae) in a rural area of southern Italy and implications for conservation. Biol Conserv 107:71-81

Russo D, Almenar D, Aihartza J, Goiti U, Salsamendi E, Garin I (2005) Habitat selection in sympatric Rhinolophus mehelyi and $R$. euryale (Mammalia: Chiroptera). J Zool (Lond) 266:327-332

Rydell J, Miller LA, Jensen ME (1999) Echolocation constraints of Daubenton's bat foraging over water. Funct Ecol 13:247-255

Sanchis-Moll EJ (ed) (1988) Guía de la naturaleza de la comunidad Valenciana. Edicions Alfons el Magnànim, València

Saunders MB, Barclay RMR (1992) Ecomorphology of insectivorous bats: a test of predictions using two morphologically similar species. Ecology 73:1335-1345

Siemers BM, Stilz P, Schnitzler HU (2001) The acoustic advantage of hunting at low heights above water: behavioural experiments on the European 'trawling' bats Myotis capaccinii, M. dasycneme and M. daubentonii. J Exp Biol 204:3843-3854

Siemers BM, Baur E, Schnitzler HU (2005) Acoustic mirror effect increases prey detection distance in trawling bats.

Editorial responsibility: Stephen Rossiter,

London, UK
Naturwissenschaften 92:272-276

Spitzenberger F, von Helversen O (2001) M. capaccinii (Bonaparte, 1837) - Langfußfledermaus. In: Krapp F (ed) Handbuch der Säugetiere Europas. AULA-Verlag, Wiebelsheim, p 281-302

Tuttle MD (1974) An improved trap for bats. J Mammal 55: 475-477

Val R, Niñerola D, Armengol J, Dolz J (2003) Incidencia de los embalses en el régimen térmico del río. El caso del tramo final del río Ebro. Limnetica 22:85-92

van de Sijpe M, Vandendriessche B, Voet P, Vandenberghe J and others (2004) Summer distribution of the pond bat Myotis dasycneme (Chiroptera, Vespertilionidae) in the west of Flanders (Belgium) with regard to water quality. Mammalia 68:377-386

> Vaughan N, Jones G, Harris S (1996) Effects of sewage effluent on the activity of bats (Chiroptera: Vespertilionidae) foraging along rivers. Biol Conserv 78:337-343

Von Frenckell B, Barclay RMR (1987) Bat activity over calm and turbulent water. Can J Zool 65:219-222

Warren RD, Waters DA, Altringham JD, Bullock DJ (2000) The distribution of Daubenton's bats (Myotis daubentonii) and pipistrelle bats (Pipistrellus pipistrellus) (Vespertilionidae) in relation to small-scale variation in riverine habitat. Biol Conserv 92:85-91

White GC, Garrot RA (1990) Analysis of wildlife radio-tracking data. Academic Press, London

Submitted: June 13, 2008; Accepted: January 7, 2009

Proofs received from author(s): April 16, 2009 